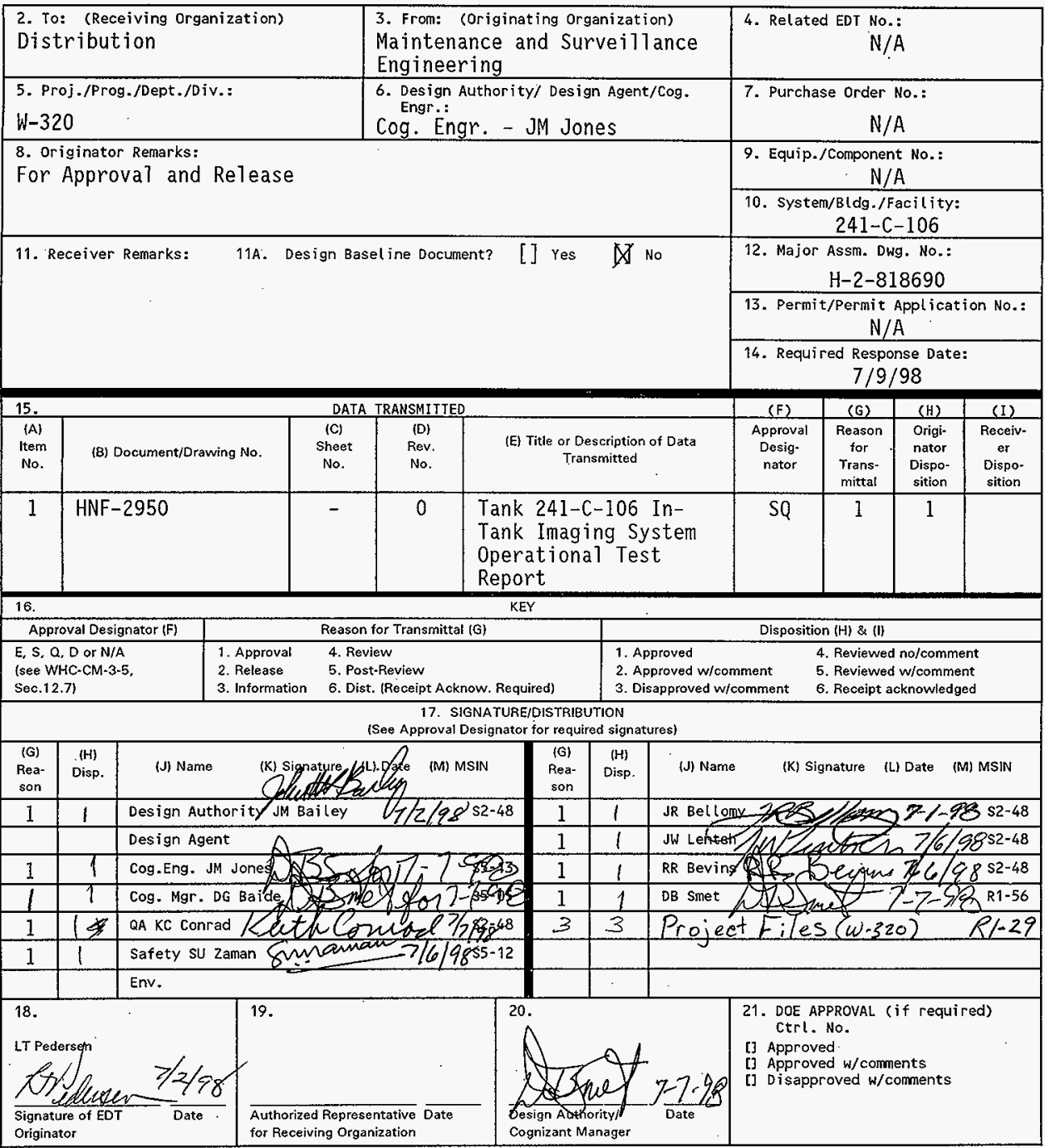

BD-7400-172-2(05/96) GEF097 
HNF-2950, Rev. 0

\title{
Tank 241-C-106 In-Tank Imaging System Operational Test Report
}

\author{
LT Pedersen \\ Lockheed Martin Hanford Company, Richland, WA 99352 \\ U.S. Department of Energy Contract DE-AC06-96RL13200
}

EDT: 617464

Org Code: 74720

UC: 506

B\&R Code: EW3130010 Total Pages: 42

Key Words: Project W-320, CCTV, camera, OTR, sluicing, C-106

Abstract: This document comprises the Operational Test Report for the Project W-320 In-Tank Imaging (CCTV) System. This document containes the completed copy of the Operational Test Procedure as an attachment.

TRADEMARK DISCLAIMER. Reference herein to any specific commercial product, process, or service by trade name, tradenark, manufacturer, or otherwise, does not necessarily constitute or imply its endorsement, recommendation, or favoring by the United States Government or any agency thereof or its contractors or subcontractors.

Printed in the United States of America. To obtain copies of this document, contact: Document Control Services, P.0. Box 950, Matlstop H6-08, Richland WA 99352, Phone (509) 372-2420; Fax (509) 376-4989.

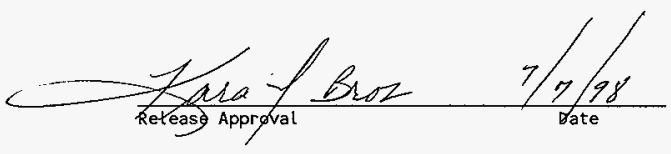

Approved for Public Release 
HNF-2950, Rev. 0

1.0 INTRODUCTION $\ldots \ldots \ldots \ldots \ldots \ldots \ldots \ldots \ldots \ldots \ldots \ldots$

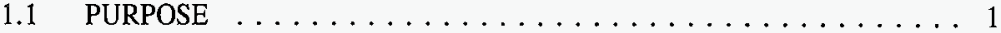

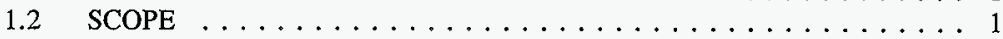

1.3 OBJECTIVE $\ldots \ldots \ldots \ldots \ldots \ldots \ldots \ldots \ldots \ldots \ldots \ldots$

2.0 EQUIPMENT DESCRIPTION $\ldots \ldots \ldots \ldots \ldots \ldots \ldots \ldots \ldots \ldots$

3.0 TEST DESCRIPTION $\ldots \ldots \ldots \ldots \ldots \ldots \ldots \ldots \ldots \ldots \ldots \ldots$

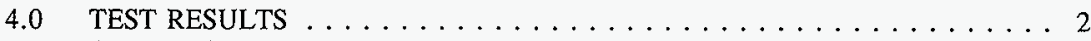

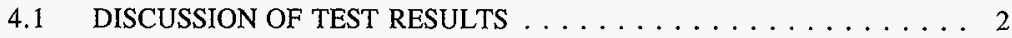

4.2 DISCUSSION OF TEST EXCEPTION $\ldots \ldots \ldots \ldots \ldots \ldots \ldots$

5.0 CONCLUSION $\ldots \ldots \ldots \ldots \ldots \ldots \ldots \ldots \ldots \ldots \ldots \ldots \ldots \ldots \ldots$

6.0 REFERENCES $\ldots \ldots \ldots \ldots \ldots \ldots \ldots \ldots \ldots \ldots \ldots \ldots$ ATTACHMENT

COMPLETED TANK FARM PLANT OPERATING

PROCEDURE OTP-320-005, REV. A-0 . . . . . . . . . . . . A 1 
HNF-2950, Rev, 0

\subsection{INTRODUCTION}

\subsection{PURPOSE}

This document presents the results of operational testing of the 241-C-106 In-Tank Video Camera Imaging System. This imaging system was installed as a component of Project W-320 to monitor sluicing and waste retrieval activities in Tank 241-C-106.

\subsection{SCOPE}

Operational testing of the 241-C-106 In-Tank Video Camera System was performed in accordance with Tank Farm Plant Operating Procedure OTP-320-005, Rev. A-0, "Tank 241-C-106 In-Tank Imaging System Operational Test Procedure". This document reports the results of that testing.

\subsection{OBJECTIVE}

The objective of testing the 241-C-106 In-Tank Video Camera Imaging System was to verify that all imaging system equipment functions in accordance with design and operating requirements.

\subsection{EQUIPMENT DESCRIPTION}

The 241-C-106 In-Tank Video Camera Imaging System consists of the In-Tank Assembly, the Master Control Station, and the Local Control Station. The In-Tank Assembly is installed in Riser 7, located on the west side of Pump Pit 241-C-06A, and consists of the camera, lights, pan-and-tilt unit, and camera mast. The Master Control Station is located in the MO211 Control Room in Cabinet CP-02, and consists of a camera controller, monitor, and video tape recorder. The Local Control Station is rack-mounted on Field Control Unit FCU-1361, on the north side of Tank 241-C-106, and consists of an auxiliary camera controller. Additional equipment, including the Hazardous Location Power Controller, Local Interface Unit, and Wash Down Solenoid are also rack-mounted on FCU-1361.

Control cables located in underground conduit runs connect the In-Tank Assembly, Master Control Station, and Local Control Station. Instrument quality compressed air for purging the camera and pan-and-tilt unit is routed in underground conduit from the Process Building (241-C-91) to the Hazardous Location Power Controller at FCU-1361. Filtered raw water for the camera wash down system is routed in underground conduit from the Process Building to the Wash Down Solenoid at FCU-1361. Above grade hoses carry the purge air and filtered water from FCU-1361 to the In-Tank Assembly. 
HNF-2950, Rev. 0

\subsection{TEST DESCRIPTION}

Operational testing of 241-C-106 In-Tank Video Camera Imaging System consisted of:

- Aligning the compressed instrument air supply and testing the Hazardous Location Power Controller purge cycle timing and power interlocks.

- Aligning the filtered water supply and testing of the camera lens and lighting wash down solenoid valve operation from the Master Control Station and from the Local Control Station.

- Operation of the camera lens focus, zoom, and iris motor controls at the Master Control Station and the Local Control Station.

- Operation of the pan-and-tilt unit motor controls and electronic brake at the Master Control Station and the Local Control Station.

- Operation of the individual camera light controls at the Master Control Station and the Local Control Station.

- Operation of the S-VHS video tape recorder and monitor at the Master Control Station.

\subsection{TEST RESULTS}

\subsection{DISCUSSION OF TEST RESULTS}

Operational testing of the 241-C-106 In-Tank Video Camera Imaging System was completed satisfactorily. There was one exception recorded during testing. The exception is discussed in the next section.

The completed copy of OTP-320-005, Rev. A-0, "Tank 241-C-106 In-Tank Imaging System Operational Test Procedure," is found as an attachment to this document.

\subsection{DISCUSSION OF TEST EXCEPTION}

One test exception was noted during the performance of OTP-320-005, Rev. A-0. A high differential pressure alarm was observed when the camera wash down system was activated for testing. This alarm was initiated by Pressure Differential Indicating Switch PDISH-13615 which monitors for pressure buildup across 30 Micron Filter F-1361 in the raw water system. The filter element was subsequently changed. At the recommendation of the filter 
HNF-2950, Rev. 0

manufacturer, PDISH-13615 was also replaced with a differential pressure switch having a wider range. The camera wash down system was retested following these changes and was found to perform satisfactorily.

\subsection{CONCLUSION}

Operational testing of the 241-C-106 In-Tank Video Camera Imaging System was successfully completed. The imaging system is acceptable for use during waste sluicing and retrieval in Tank 241-C-106.

\subsection{REFERENCES}

H-2-818592, Sh. 1 In-Tank Imaging Cab CP-02 Assembly and Section

H-2-818690, Sh. $1 \quad$ C-Farm In-Tank Imaging (CCTV)

H-2-818704, Sh. $1 \quad$ C-Farm Pump Pit Details

HNF-1824

Acceptance Test report for the Tank 241-C-106 In-Tank Imaging System

JCS\#2E-97-2230

Job Control System Work Package, C-106 In-Tank Imaging (CCTV) Installation

OTP-320-005

Tank 241-C-106 In-Tank Imaging System Operational Test Procedure

VI No. 22668, Supp.105 Vendor Information, In-Tank Imaging System 
HNF-2950, Rev. 0

\author{
ATTACHMENT \\ COMPLETED TANK FARM PLANT OPERATING \\ PROCEDURE OTP-320-005, REV. A-0 \\ "TANK 241-C-106 IN-TANK IMAGING SYSTEM \\ OPERATIONAL TEST PROCEDURE"
}




\section{TANK 241-C-106 IN-TANK IMAGING SYSTEM OPERATIONAL TEST PROCEDURE}

\begin{tabular}{|c|c|c|}
\hline \multicolumn{3}{|c|}{$\begin{array}{l}\text { Last Ful1 Revision: A-0 } \\
\text { Release Date: 5/11/98 } \\
\text { USQ Screening Number: TF-98-0319 } \\
\text { Approval Designator: ESQ }\end{array}$} \\
\hline POSITION/ORG & DELEGATE & DATE \\
\hline NCO & D.R. Jones & $4 / 29 / 98$ \\
\hline Shift Manager & K.J. Anderson & $4 / 30 / 98$ \\
\hline QA Engineer & W.L. Adams & $4 / 30 / 98$ \\
\hline Safety Engineer & S.U. Zaman & $5 / 5 / 98$ \\
\hline Environmental Eng. & P.C. Miller & $5 / 6 / 98$ \\
\hline RadCon Engineer & J. Pieper & $4 / 30 / 98$ \\
\hline COG Engineer & J.M. Jones & $5 / 6 / 98$ \\
\hline Acceptance Review & D.C. Ashworth & $\underline{5 / 11 / 98}$ \\
\hline Approval Authority & T.J. Kelley & $5 / 11 / 98$ \\
\hline Justification: Eng & eering Request & \\
\hline
\end{tabular}

HNF-2950, Rev. 0

A-2 


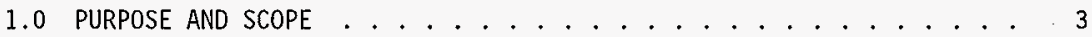

1.1 PURPOSE . . . . . . . . . . . . . . 3

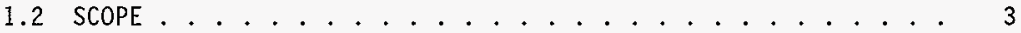

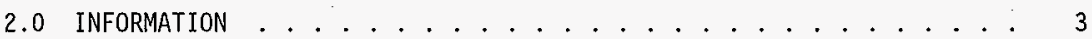

2.1 TERMS AND DEFINITIONS .................... 3

2.2 RESPONSIBILITIES . . . . . . . . . . . . . 3

2.3 REFERENCES .................... . . . . 4

2.4 GENERAL INFORMATION . . . . . . . . . . . . . 5

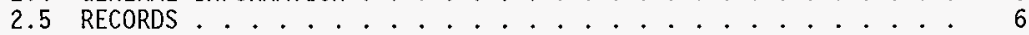

3.0 PRECAUTIONS AND LIMITATIONS . . . . . . . . . . . . . . . 7

3.1 PERSONNEL SAFETY . . . . . . . . . . . . . . . . . 7

3.2 RADIATION AND CONTAMINATION CONTROL . . . . . . . . 7

3.3 LIMITS . . . . . . . . . . . . . . . . . . . 7

4.0 PREREQUISITES . . . . . . . . . . . . . . . . . . . . . 8

4.1 SPECIAL TOOLS, EQUIPMENT, AND SUPPLIES ......... 8

4.2 PERFORMANCE DOCUMENTS . . . . . . . . . . . . . . . . 8

4.3 CONDITIONS AND ACTIONS ................ 8

5.0 PROCEDURE . . . . . . . . . . . . . . . . . . . . 10

5.1 ALIGN CAMERA FLUSH WATER ............. 10

5.2 ALIGN AND TEST CAMERA PURGE AIR . . . . . . . . . . . 10

5.3 TEST MASTER CONTROL STATION . . . . . . . . . . . 12

5.4 TEST LOCAL CONTROL STATION . . . . . . . . . . . . . 18

5.5 TEST CLOSEOUT . . . . . . . . . . . . . . 23

ATTACHMENT 1 - OTP-320-005 TEST LOG . . . . . . . . . 25

ATTACHMENT 2 - OTP-320-005 TEST EXCEPTION REPORT . . . . . . . 26

ATTACHMENT 3 - OTP-320-005 SIGNATURE LOG . . . . . . . . . 27

ATTACHMENT 4 - OTP-320-005 ELECTRICAL LINEUP . . . . . . . . . . . 28

ATTACHMENT 5 - OTP-320-005 RAW WATER VALVE LINEUP . . . . . . . . 29

ATTACHMENT 6 - OTP-320-005 COMPRESSED AIR VALVE LINEUP . . . . . . 30

ATTACHMENT 7 - OTP-320-005 ALARM RESPONSE . . . . . . . . 31

PROCEDURE HISTORY SIGNATURE SHEET . . . . . . . . . . . 35

HNF-2950, Rev. 0

A-3

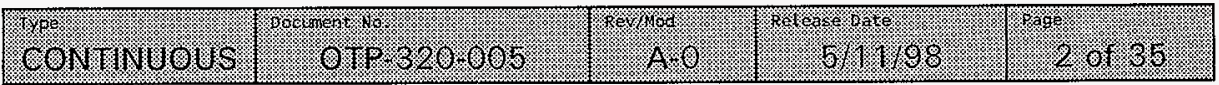




\subsection{PURPOSE AND SCOPE}

\subsection{PURPOSE}

This operational test procedure provides instructions for startup and testing of the Waste Retrieval Sluicing System (WRSS) In-Tank Imaging System. The In-Tank Imaging System monitors and records tank 241-C-106 waste retrieval and sluicing activities.

\subsection{SCOPE}

This procedure tests Imaging System equipment from both the Master Control Station, located in Control Room M0-211, and from the Local Control Station, located at Field Control Unit FCU-1361, adjacent to Tank 241-C-106. This test applies to operation of the in-tank camera, recording equipment, camera wash down system, and the camera purge and cooling/drying air system:

\subsection{INFORMATION}

\subsection{TERMS AND DEFINITIONS}

WRSS - Waste Retrieval sluicing System

\subsection{RESPONSIBILITIES}

\subsubsection{Test Engineer:}

- Provides technical support during testing

- Provides programming support during testing

- Reviews test documents to val idate acceptance

- Records equipment status and data per this procedure

- Records data exceptions and other notes as required on the OTP Data Sheets

- Prepares post testing documents.

2.2.2 Nuclear Chemical Operators (Surveillance Certified):

- Operate Imaging System equipment and components associated with this operational test procedure

- Perform all operations required by this operational test procedure.

HNF-2950, Rev. 0

A-4 


\subsection{RESPONSIBILITIES (Cont.)}

2.2.3 Quality Control Inspector:

- Verifies that procedure sections were performed properly by witnessing procedure steps as they occur

2.2.4 Quality Assurance Engineer

- Reviews and approves exception resolutions as determined by the Test Director

- Reviews recorded test data for accuracy and completeness.

2.2.5 Test Director:

- Verifies prerequisites complete prior to start of test

- Provides overali control of the testing process and change record authorization for this operational test

- Ensures all required data is collected

- Ensures safe and productive accomplishment of testing

- Ensures safe working conditions and practices

- Ensures compliance with test documents and Technical Safety Requirements/Documents (TSRs/OSDs) during testing

- Communicates and coordinates testing with DST Shift Manager

- Ensures review and approval of a11 modifications to test procedures are completed prior to return to testing

- Acts as direct line of communication and centralized point of control during normal, abnormal, and casualty situations

- Conducts pre-job briefings as required

- Schedules/reschedules tests as required

- Conducts pre-job system walkdowns

- Reviews test documents to validate acceptance

- Verifies all test instrumentation is within current calibration cycie.

\subsection{REFERENCES}

- $\quad H-2-818559$, Project W-320 P \& ID Tank 241-C-106.

- H-2-818561, Project W-320 P \& ID TK 241-C-106 HVAC.

- H-2-818562, Project W-320 P \& ID Air \& Water System.

- H-2-818592, Instrumentation In-Tank Imaging Cab CP-02 Assembly \& Section.

- H-2-818678, Sht 3, Electrical C-Farm Process Bldg Plan \& Details.

- $\quad H-2-818680$, Electrical C-Farm One-Line Diagram.

- H-2-818690, Electrical C-Farm In-Tank Imaging System

HNF-2950, Rev. 0

A-5 


\subsection{GENERAL INFORMATION}

\subsubsection{CHANGE CONTROL}

Change control shall be in accordance with HNF-IP-0842.

\subsubsection{TEST EXCEPTIONS}

Components that cannot be brought into the range of acceptance specified by the applicable inspection or testing maintenance procedure shall be identified, processed and controlled as test exceptions.

Test exceptions are used to document unexpected results and identify appropriate actions, not to circumvent performance requirements.

A11 test exceptions shall be given a sequential number and recorded on Attachment 1, OTP-320-005 TEST LOG.

Attachment 2, OTP-320-005 TEST EXCEPTION REPORT, shall be filled out to record and disposition each test exception.

\section{$2.4 .3 \quad$ ALARM RESPONSE}

A1 arm response procedure ARP-T-331-00004, Respond to A1arms at Service Building 241-C-73, identifies alarms associated with the Compressed Air and Raw Water Systems operated in support of this test and provides instructions for responding to those alarms.

Attachment 7, OTP-320-005 ALARM RESPONSE identifies air and water system alarms at Process Building 241-C-91 and Control Room MO-211 that may also be expected during this test and provides instructions for responding to those alarms.

Unexpected alarms received during testing, that are associated with this test, shall be logged as test exceptions and evaluated by the Test Director for effect on the test.

2.4.4 If changing conditions affect testing, or delays extend test duration past the end of the testing shift, the Test Director and Test Engineer need to be contacted for additional instructions.

HNF-2950, Rev. 0

A-6 


\subsection{GENERAL INFORMATION (Cont.)}

2.4.5 If during performance of this procedure, any of the following conditions are found, IMMEDIATELY notify the assigned Test Director and Test Engineer:

- Any equipment malfunction which could prevent fulfillment of functional requirements

- Personnel error or procedural inadequacy which could prevent fulfillment of procedural requirements

- Any other unexpected anomalies.

The Test Director shall assess the effect on the system and the test, and direct either continuation of the test in the same section, proceeding to another attachment or section of the test, or suspension of the test per step 2.4.7 and establishing a safe condition for equipment.

\subsubsection{SYSTEM STATUS}

Record a11 changes in equipment configuration, comments and observations by participants, and any other data pertinent to the test on Attachment 1, OTP-320-005 TEST LOG.

\subsubsection{SUSPENSION OF TEST AND RESUMING TEST}

Test Director may unilaterally, for any reason, stop testing, and place equipment in a safe condition. All suspension of testing shall be documented on Attachment 1, OTP-320-005 TEST LOG.

If a section of the test is suspended for any reason prior to completing all steps, the Test Director shall establish initial conditions necessary to resume testing for that section. Previously completed sections need not be repeated unless directed by the Test Director to establish conditions required to resume the test.

\subsection{RECORDS}

The performance copy of the operational test procedure, including completed attachments, shall be filed as a permanent test record (Operational Test Report).

HNF-2950, Rev. 0

A-7 


\subsection{PRECAUTIONS AND LIMITATIONS}

\subsection{PERSONNEL SAFETY}

- The flexible pneumatic hose downstream of valve HV-13676 may contain pressurized instrument air.

- The flexible hose downstream of valve HV-13657 may contain pressurized water.

\subsection{RADIATION AND CONTAMINATION CONTROL}

- Work in radiological areas will be performed using a Radiation Work Permit following review by Radiological Control Engineering and Technical Support.

\subsection{LIMITS}

- If testing is interrupted or the In-Tank Imaging System is shutdown for an extended period (longer than one hour), the viewing lights should be shut down to preserve component 1 ife.

- Viewing lights should be turned off and allowed to cool down for about 5 minutes before performing washdown. Lamps are rated for exposure to wash water while at full operating temperature; however, a brief cooldown period ( 5 minutes) before washing is desirable to preserve component life.

HNF-2950, Rev. 0

A -8 


\subsection{PREREQUISITES}

\subsection{SPECIAL TOOLS, EQUIPMENT, AND SUPPLIES}

- Timing device

- Blank S-VHS format video tape

- Auxiliary TV monitor (for Local Control Station test)

\subsection{PERFORMANCE DOCUMENTS}

- T0-320-010, 0perate WRSS Raw Water System.

- T0-320-012, 0perate WRSS Compressed Air System.

- ARP-T-331-00004, Respond to Alarms at Service Building 241-C-73

\subsection{CONDITIONS AND ACTIONS}

4.3.1 Perform a Pre-Job Briefing with all personnel involved in the performance of this operational test. The pre-job briefing is an ongoing activity that is to be performed by each Test Director.

4.3.2 ATl personnel to be involved with performance of this procedure have completed Attachment 3, OTP-320-005 SIGNATURE LOG. Signature Log completion is an ongoing requirement for each individual that becomes involved in the performance of this operational test.

4.3.3 Electrical circuit breakers and disconnects associated with In-Jank Imaging System operation are positioned per Attachment 4, 0TP-320-005 ELECTRICAL LINEUP, or as directed by Test Director.

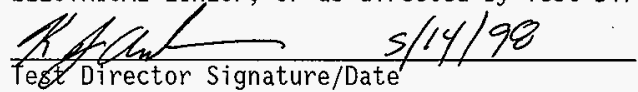

HNF-2950, Rev. 0

A- 9 


\subsection{CONDITIONS AND ACTIONS (Cont.)}

4.3.4 Camera flush water supply is aligned for service as follows:

- Flush water isolation valve, HV-13657 (located near CAMERA WASHDOWN CONTROL BOX on FCU-1361) is CLOSED.

\section{CAUTION}

The valve 1 ineup in Attachment 5 isolates all Process Building 241-C-91 raw water service except to the In-Tank Imaging System.

- Process Building 241-C-91 raw water valves are aligned per Attachment 5, OTP-320-005 RAW WATER VALVE LINEUP, or as directed by Test Director.

- Raw Water System is in service per T0-320-010, Operate WRSS Raw Water System.

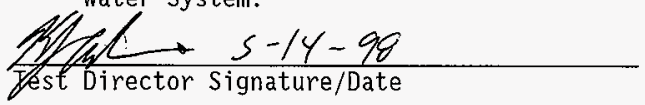

4.3.5 Camera purge and cooling/drying air supply is aligned for service as follows:

- Purge air isolation valve, HV-13676 (located near Hazardous Location Power Controller on FCU-1361) is CLOSED.

\section{CAUTION}

This valve lineup isolates all Process Building 241-C-91 compressed air service except to the In-Tank Imaging system.

- Process Building 241-C-91 instrument air valves are positioned per Attachment 6, OTP-320-005 COMPRESSED AIR VALVE LINEUP, or as directed by Test Director.

- Compressed Air System is in service per T0-320-012, Operate WRSS Compressed Air System.

Test Director Signature/Date.

HNF-2950, Rev. 0 A-10 


\subsection{PROCEDURE}

\subsection{ALIGN CAMERA FLUSH WATER}

NOTE: Raw water supply pressure up to PCV-13620 is 110 to $150 \mathrm{psig.}$

5.1.1 ENSURE shutoff valve, HV-1367, inside FCU-1361 CAMERA WASHDOWN CONTROL BOX is OPEN.

5.1.2 ENSURE flexible water 1 ine from CAMERA WASHDOWN CONTROL BOX is connected to Upper Junction Box connector on 241-C-106 Camera Riser \#7.

5.1.3 OPEN flush water valve HV-13657, located adjacent to CAMERA WASHDOWN CONTROL BOX on FCU-1361.

5.1.4 Section 5.1 has been satisfactorily completed.

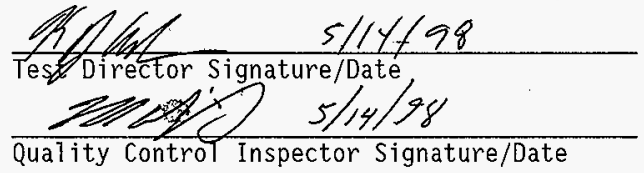

\subsection{ALIGN AND TEST CAMERA PURGE AIR}

5.2.1 VERIFY instrument air pressure is 90 to 110 psig on Process Building 241-C-91 pressure indicator, PI-13628.

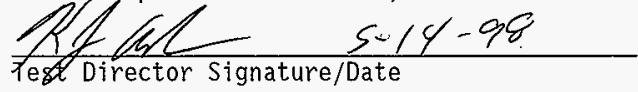

5.2.2 ENSURE flexible air line from Hazardous Location Power Controller is connected to upper junction box connector on 241-C-106 Camera Riser \#7.

5.2.3 OPEN instrument air valve HV-13676, located near Hazardous Location Power Controller on FCU-1361.

5.2.4 ENSURE Hazardous Location Power Controller power ON/OFF switch is ON.

5.2.5 VERIFY Hazardous Location Power Controller INLET PRESSURE gage reads 30 to $40 \mathrm{psig}$.

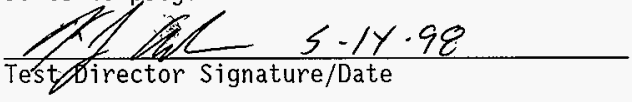

FNF-2950, Rev. 0

A-11

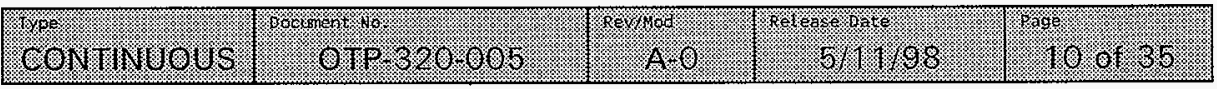




\subsection{ALIGN AND TEST CAMERA PURGE AIR (Cont.)}

NOTE - The Hazardous Location Power Controller will not al1ow camera startup until 10 purge volumes have passed through it (19 to 25 minutes).

5.2.6 START camera purge time delay period by pressing Hazardous Location Power Controller RESET pushbutton.

5.2.7 VERIFY Hazardous Location Power Control1er red ENERGIZED 1 amp comes on after a purge time delay of 19 to 25 minutes.

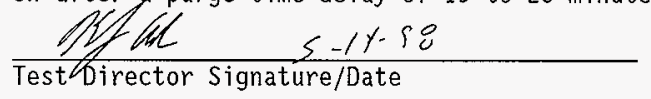

5.2.8 IF red ENERGIZED 7 amp does NOT come on after 25 minutes, PRESS

Hazardous Location Power Controller RESET pushbutton, AND

NoTIFY Test Director.

5.2.9 CLOSE instrument air valve HV-13676.

NOTE - Hazardous Location Power Controller trips camera system power when low differential pressure in the pan and tilt enclosure, is detected, or when low air flow is detected.

5.2.10 VERIFY red ENERGIZED lamp turns off.

Test $5-14-98$

5.2.11 OPEN instrument air valve HV-1.3676.

NOTE - Operations personnel may proceed to Control Room M0-21l and prepare for Section 5.3 during camera purge time delay period.

5.2.12 PRESS Hazardous Location Power Controller RESET pushbutton.

5.2.13 Section 5.2 has been satisfactorily completed.

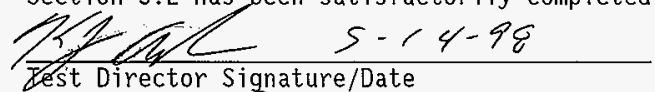

Dest Director Signature/Date

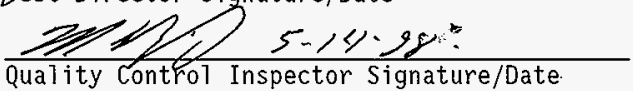

HNF-2950, Rev. 0

A-12 


\subsection{TEST MASTER CONTROL STATION}

5.3.1 START Color Camera Control Unit, TV Monitor, and Video Tape Recorder:

NOTE - This component configuration requires the Video Tape Recorder to be energized and tuned to channel Al for an image to be transmitted to the TV Monitor, even if recording is not desired.

5.3.1.1 PRESS POWER pushbuttons on COLOR CAMERA CONTROL UNIT, Video Tape Recorder, and TV Monitor (indicator lights come ON).

5.3.1.2 ENSURE that the Video Tape Recorder is tuned to channel Al.

5.3.1.3 CHECK that TV Monitor is operational and a color image is present.

5.3.2 TEST camera lighting system and variable controllers:

5.3.2.1 PLACE LIGHTS toggle switch to ON.

5.3.2.2 HOLD each dimmer toggle DOWN for 10 seconds AND

VERIFY that intensity of each viewing light gets brighter.

If $10<-14-58$

5.3.2.3 HOLD each dimmer toggle UP for 10 seconds AND

VERIFY that ibtensity of each viewing light gets dimmer.

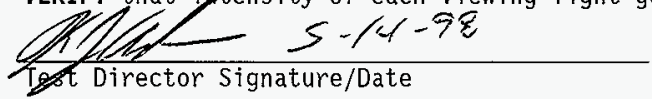

5.3.2.4 SET 1ights to desired intensity for viewing.

NOTE - Camera position is mid-range when on-screen position display reads PAN-180.

5.3.3 TEST left and right camera pan response:

5.3.3.1 PRESS LEFT and then RIGHT pan control buttons AND

VERIFY TV Monitor image pans left and then right and on-screen camera posjtion display decreases and increases.

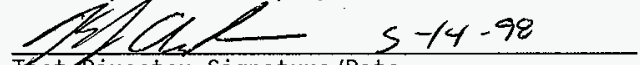

Test Director Signature/Date

5.3.3.2 RETURN camera to a mid-range pan position as desired.

HNF-2950, Rev. 0

A-13

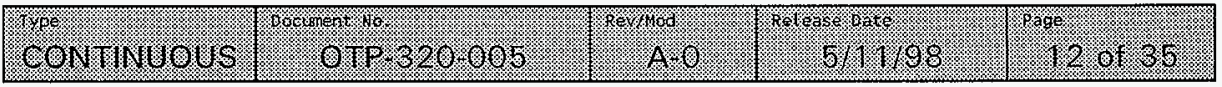




\subsection{TEST MASTER CONTROL STATION (Cont.)}

5.3.4 TEST camera pan rate speed:

5.3.4.1 PRESS AND HOLD LEFT pushbutton.

5.3.4.2 PRESS PAN speed toggle control upwards and then downwards AND VERIFY that camera pan speed increases and then decreases.

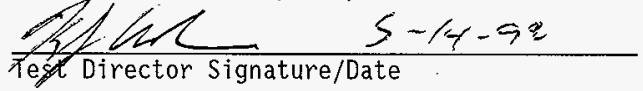

5.3.4.3 RELEASE LEFT pushbuttion.

5.3.4.4 PRESS AND HOLD RIGHT pushbutton.

5.3.4.5 PRESS PAN speed toggle control upwards and then downwards AND VERIFY that camera pan speed increases and then decreases.

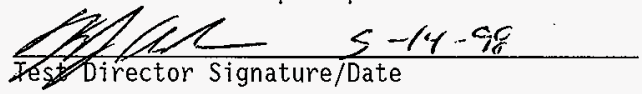

5.3.4.6 RELEASE RIGHT pushbutton.

5.3.5 TEST pan motor electronic brake:

5.3.5.1 PRESS AND HOLD LEFT pushbutton until camera stop is reached AND VERIFY pan electronic brake holds by observing that TV Monitor image and on-screen camera position display remain stationary.

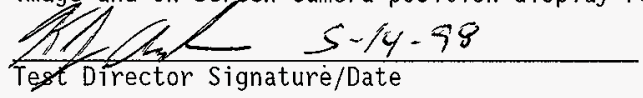

5.3.5.2 PRESS AND HOLD RIGHT pushbutton until camera stop is reached AND VERIFY pan electronic brake holds by observing that TV Monitor image and on-screen camera position display remain stationary.

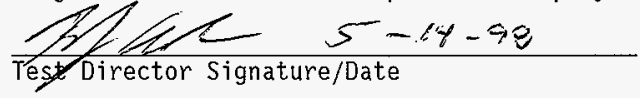

5.3.5.3 RETURN camera to a mid-range pan position as desired.

HNF-2950, Rev. 0

A-14

\begin{tabular}{|c|c|c|c|c|}
\hline 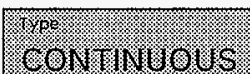 & o. & (3.). & (2) $6.1 \%$ & 1. \\
\hline
\end{tabular}




\subsection{TEST MASTER CONTROL STATION (Cont.)}

NOTE - Camera position is mid-range when on-screen position display reads TILT-090.

5.3.6 TEST up and down camera tilt response:

5.3.6.1 PRESS UP and then DOWN tilt control buttons.

5.3.6.2 VERIFY TV Monitor image moves up and then down and on-screen camera position display decreases and increases.

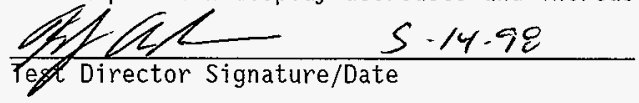

5.3.6.3 RETURN camera to a mid-range tilt position as desired.

5.3.7 TEST camera tilt rate speed:

5.3.7.1 PRESS AND HOLD UP pushbutton.

5.3.7.2 PRESS TILT speed toggle control upwards and then downwards AND VERIEY that camera tilt speed increases and then decreases.

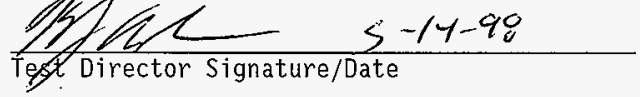

5.3.7.3 RELEASE UP pushbutton.

5.3.7.4 PRESS AND HOLD DOWN pushbutton.

5.3.7.5 HOLD TILT speed toggle control upwards and then downwards AND VERIFY that camera tilt speed increases and then decreases.

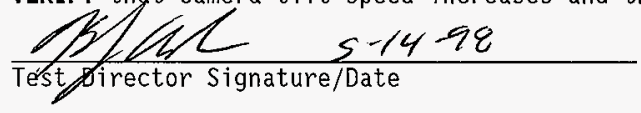

5.3.7.6 RELEASE DOWN pushbutton.

HNF-2950, Rev. 0

A-15 


\subsection{TEST MASTER CONTROL STATION (Cont.)}

5.3.8 TEST tilt motor electronic brake:

5.3.8.1 PRESS AND HOLD UP pushbutton unti 1 camera stop is reached AND VERIFY tilt electronic brake holds by observing that TV Monitor image and on-screen camera position display remain stationary. pest firector signature/Date $-5-14-98$

5.3.8.2 PRESS AND HOLD DOWN pushbutton until camera stop is reached AND VERIFY tilt electronic brake holds by observing that TV Monitor image and on-screen camera position display remain stationary.

Test Director signature/Date

5.3.8.3 RETURN camera to a mid-range tilt position as desired.

5.3.9 TEST camera viewing controls:

5.3.9.1 PRESS FOCUS toggle control towards NEAR and then FAR AND VERIFY camera focus adjusts to bring closeup and then far away objects into focus by observing TV Monitor image.

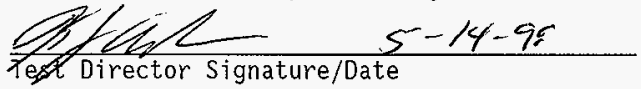

5.3.9.2 PRESS IRIS toggle control towards OPEN and then CLOSE AND VERIFY that camera iris opens and then closes by observing that TV Monitor image gets brighter and then dimmer.

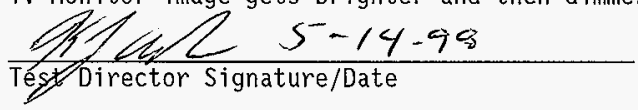

5.3.9.3 PRESS ZOOM control towards TELEPHOTO and then WIDE AND

VERIFY that TV Monitor image gets larger and then smaller.

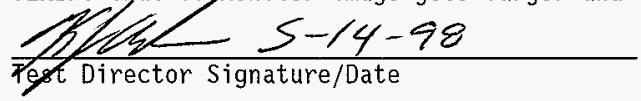

5.3.9.4 ADJUST FOCUS, IRIS and ZOOM controls as desired for viewing.

HNF-2950, Rev. 0

A-16 


\subsection{TEST MASTER CONTROL STATION (Cont.)}

5.3.10 TEST camera water washdown system:

NOTE - Lamps are rated for exposure to wash water while at full operating temperature; however, a brief cooldown period before washing is desirable to preserve component life.

5.3.10.1 PLACE LIGHTS toggle switch to OFF AND

ALLOW 1 amps to cool for 5 minutes.

NOTE - The water washdown system requires a minimum of 10 seconds to activate.

5.3.10.2 PRESS AND HOLD the HOLD TO WASH pushbutton.

5.3.10.3 PLACE LIGHTS toggle switch to ON AND

VERIFY water washdown has activated by observing water spray on TV Monitor.

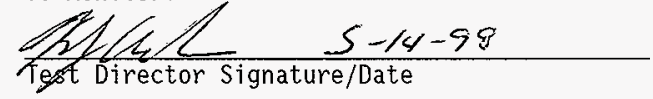

5.3.10.4 RELEASE HOLD TO WASH button.

5.3.11 TEST Video Tape Recorder for recording and playback:

5.3.11.1 ENSURE S-VHS selector switch is set to ON.

5.3.11.2 ENSURE RECORDING SP/SLP switch is set to SP.

5.3.11.3 PLACE blank S-VHS format video tape into Video Tape Recorder.

5.3.11.4 PRESS REC button to begin recording.

5.3.11.5 RECORD a brief scene whiTe panning and/or tilting camera viewing angle.

5.3.11.6 PRESS STOP button to end recording.

5.3.11.7 PRESS REW button to rewind video tape.

5.3.11.8 PRESS PLAY button to play video tape.

HNF-2950, Rev. 0

A-17 


\subsection{TEST MASTER CONTROL STATION (Cont.)}

5.3.11.9 VERIFY TV Monitor image shifts to scene recorded in Step 5.3,11.5.

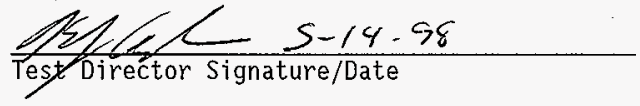

5.3.11.10 PRESS REW button to rewind video tape.

5.3.11.11 PRESS EJECT button to remove video tape.

5.3.12 PAN north AND TILT up to minimize camera lens radiation exposure.

5.3.13 PLACE LIGHTS toggle switch to OFF.

5.3.14 Section 5.3 has been satisfactorily completed.

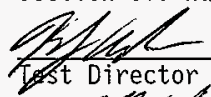

$5-14-98$

Quatity contfol Inspector Signature/Date

HNF-2950, Rev. 0

A-18 


\subsection{TEST LOCAL CONTROL STATION}

5.4.1 START COLOR CAMERA CONTROL UNIT and auxiliary TV Monitor:

5.4.1.1 ENSURE COLOR CAMERA CONTROL UNIT and auxiliary TV Monitor are properly connected.

5.4.1.2 ENERGIZE auxiliary TV Monitor AND

CHECK that a color image is present.

5.4.2 TEST camera lighting system and variable controllers:

5.4.2.1 PLACE LIGHTS toggle switch to ON.

5.4.2.2 HOLD each dimmer toggle down for about 10 seconds AND VERIFY that intensity of each viewing 1 ight gets brighter.

$\frac{7 / 2 / 2}{\text { Test Director Signature/Date }}$

5.4.2.3 HOLD each dimmer toggle up for about 10 seconds AND VERIFY that intensity of each viewing light gets dimmer.

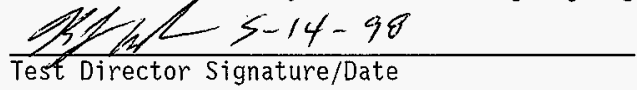

5.4.2.4 SET lights to desired intensity for viewing.

NOTE - On-screen camera position display does not read out at the Local Control Station. Camera position may be requested from the M0-211 Control Room Operator as required.

5.4.3 TEST left and right camera pan response:

5.4.3.1 PRESS LEFT and then RIGHT pan control buttons AND

VERIFY TV Monitor image pans left and then right.

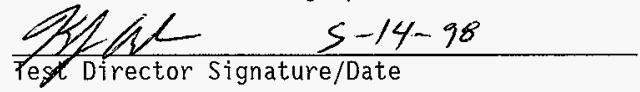

5.4.3.2 RETURN camera to a mid-range pan position as desired.

HNF-2950, Rev. 0

A-19

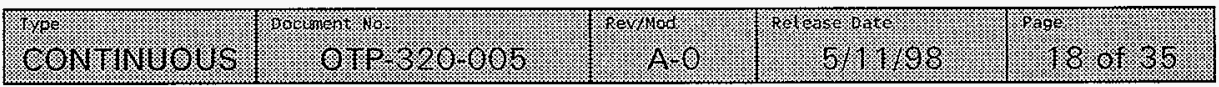




\subsection{TEST LOCAL CONTROL STATION (Cont.)}

5.4.4 TEST camera pan rate speed:

5.4.4.1 PRESS AND HOLD LEFT pushbutton.

5.4.4.2 PRESS PAN speed toggle control upwards and then downwards AND VERIFY that camera pan speed increases and then decreases.

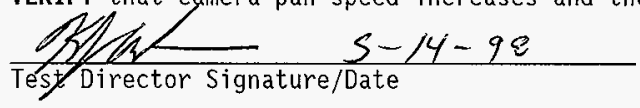

5.4.4.3 RELEASE LEFT pushbutton.

5.4.4.4 PRESS AND HOLD RIGHT pushbutton.

5.4.4.5 PRESS PAN speed toggle control upwards and then downwards AND VERIFY that camera pan speed increases and then decreases.

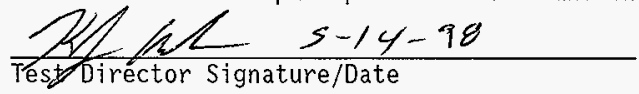

5.4.4.6 RELEASE RIGHT pushbutton.

5.4.5 TEST pan motor electronic brake:

5.4.5.1 PRESS AND HOLD LEFT pushbutton until camera stop is reached AND VERIFY pan electronic brake holds by observing that TV Monitor image remains stationary.

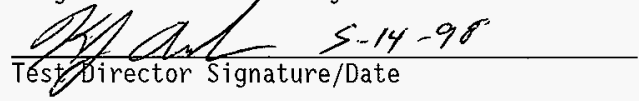

5.4.5.2 PRESS AND HOLD RIGHT pushbutton until camera stop is reached AND VERIFY pan electronic brake holds by observing that TV Monitor image remains stationary.

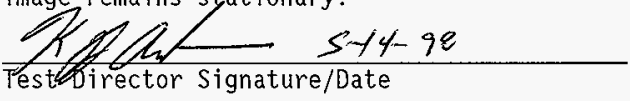

5.4.5.3 RETURN camera to a mid-range pan position as desired.

HNF-2950, Rev. 0 


\subsection{TEST LOCAL CONTROL STATION (Cont.)}

NOTE - On-screen camera position display does not read out at the Local Control Station. Camera position may be requested from the $\mathrm{MO}-211$ Control Room Operator as required.

5.4.6 TEST up and down camera tilt response:

5.4.6.1 PRESS UP and then DOWN tilt control buttons AND

VERIFY TV Monitor image moves up and then down.

Test Director Signature/Date

5.4.6.2 RETURN camera to a mid-range tilt position as desired.

\subsubsection{TEST camera tilt rate speed:}

5.4.7.I PRESS AND HOLD UP pushbutton.

5.4.7.2 PRESS TILT speed toggle control upwards and then downwards AND VERIEY that camera tilt speed increases and then decreases.

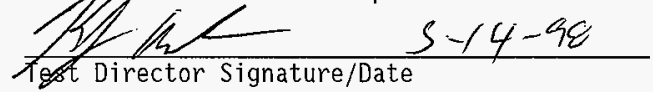

5.4.7.3 RELEASE UP pushbutton.

5.4.7.4 PRESS AND HOLD DOWN pushbutton.

5.4.7.5 HOLD TILT speed toggTe control upwards and then downwards AND VERIFY that camera tilt speed increases and then decreases.

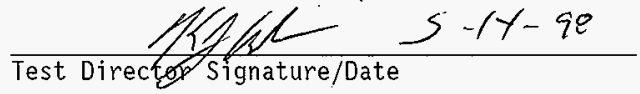

5.4.7.6 RELEASE DOWN pushbutton.

HNF-2950, Rev. 0 


\subsection{TEST LOCAL CONTROL STATION (Cont.)}

5.4.8 TEST tilt motor electronic brake:

5.4.8.1 PRESS AND HOLD UP pushbutton until camera stop is reached AND VERIFY tilt electronic brake hoids by observing that TV Monitor image remains stationary.

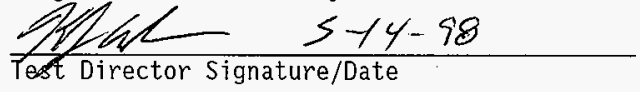

5.4.8.2 PRESS AND HOLD DOWN pushbutton unti1 camera stop is reached AND VERIFY tilt electronic brake holds by observing that TV Monitor image remains stationary.

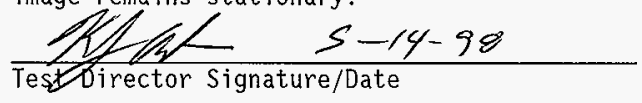

5.4.8.3 RETURN camera to a mid-range tilt position as desired.

\subsubsection{TEST camera viewing controls:}

5.4.9.1 PRESS FOCUS toggle control towards NEAR and then FAR AND VERIFY camera focus adjusts to bring closeup and then far away objects into focus by observing TV Monitor image.

Test Director Signature/Date

5.4.9.2 PRESS IRIS toggie control towards OPEN and then CLOSE AND

VERIFY that camera iris opens and then closes by observing that TV Monitor image gets brighter and then dimmer.

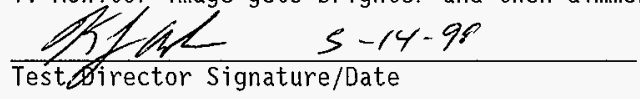

5.4.9.3 PRESS ZOOM control towards TELEPHOTO and then WIDE AND

VERIFY that TV Monitor image gets 1 arger and then smaller.

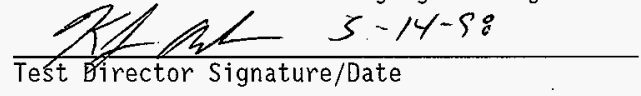

5.4.9.4 ADJUST FOCUS, IRIS and ZOOM controls as desired for viewing.

HNF-2950, Rev. 0

A-22 


\subsection{TEST LOCAL CONTROL STATION (Cont.)}

5.4.10 TEST camera water washdown system:

NOTE - Lamps are rated for exposure to wash water while at ful1 operating temperature; however, a brief cooldown period before washing is desirable to preserve component life.

5.4.10.1 PLACE LIGHTS toggle switch to OFF AND

ALLOW T amps to cool for about 5 minutes.

NOTE - The water washdown system requires a minimum of 10 seconds to activate.

5.4.10.2 PRESS AND HOLD the HOLD TO WASH pushbutton.

5.4.10.3 PLACE LIGHTS toggle switch to ON AND

VERIFY water washdown has activated by observing water spray on TV Monitor.

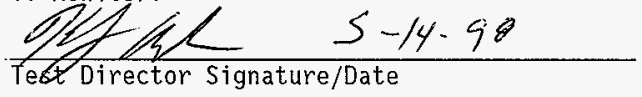

\subsubsection{RELEASE HOLD TO WASH button.}

5.4.11 PAN north AND TILT up to minimize camera lens radiation exposure.

5.4.12 PLACE LIGHTS toggle switch to OFF.

5.4.13 Section 5.4 has been satisfactorily completed.

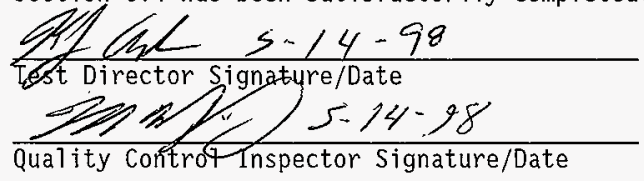

HNF-2950, Rev. 0

A-23 


\subsection{TEST CLOSEOUT}

5.5.1 DEPRESSURIZE camera flush water supply.

5.5.1.1 CLOSE Process Building 241-C-91 Imaging System supply valve, HV-136108.

5.5.1.2 PRESS AND HOLD the HOLD TO WASH pushbutton for about 1 minute AND

OBSERVE pressure indicator on PCV-13620 to verify that the flush water line depressurizes.

5.5.1.3 CLOSE FCU-1361 flush water isolation valve HV-13657 (located near CAMERA WASHDOWN CONTROL BOX On FCU-1361).

5.5.2 SHUT DOWN Local Control Station equipment.

5.5.2.1 DEENERGIZE auxiliary TV Monitor.

5.5.2.2 DISCONNECT COLOR CAMERA CONTROL UNIT and Auxi1iary TV Monitor.

NOTE - Dup7ex 15A GFCI receptacle on FCU-1361 (241-C-91, C106-PP1, breaker 9) is housed in a NEMA-4 weatherproof enclosure, and may be left energized for field use at the Test Director's discretion.

5.5.2.3 POSITION Process Building 241-C-91, C106-PPl circuit breakers \#6, IN-TANK CCTV FCU-1361, and \#9, RECPT AT FCU-1361 to OFF.

5.5.3 DEPRESSURIZE camera purge air supp Ty.

5.5.3.1 CLOSE Process Building 241-C-91 instrument air valve HV-1369.

5.5.3.2 CLOSE FCU-136I instrument air valve HV-13676.

5.5.4 SHUT DOWN Master Control Station equipment.

5.5.4.1 DEENERGIZE COLOR CAMERA CONTROL UNIT, TV Monitor and Video Tape Recorder by pressing their respective POWER pushbuttons.

5.5.4.2 POSITION Control Room M0-211, PNL-M0211 circuit breaker \#3, CP-02 IN TANK IMAGING RCPTS, to OFF.

HNF-2950, Rev. 0

A-24

\begin{tabular}{|c|c|}
\hline & 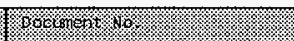 \\
\hline ron minous & . \\
\hline
\end{tabular}




\subsection{TEST CLOSEOUT (Cont.)}

5.5.5 Quality Control Inspector shall review completed test results for completeness and accuracy.

IF test documentation review is acceptable the Quality Control Inspector shall sign below.

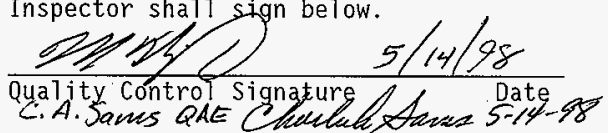

5.5.6 All components and equipment are secure from testing. Testing is complete.

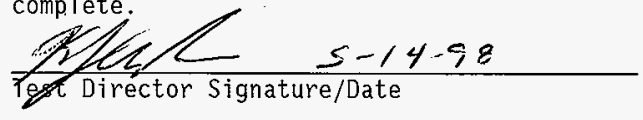

HNF-2950, Rev. 0

A -25 


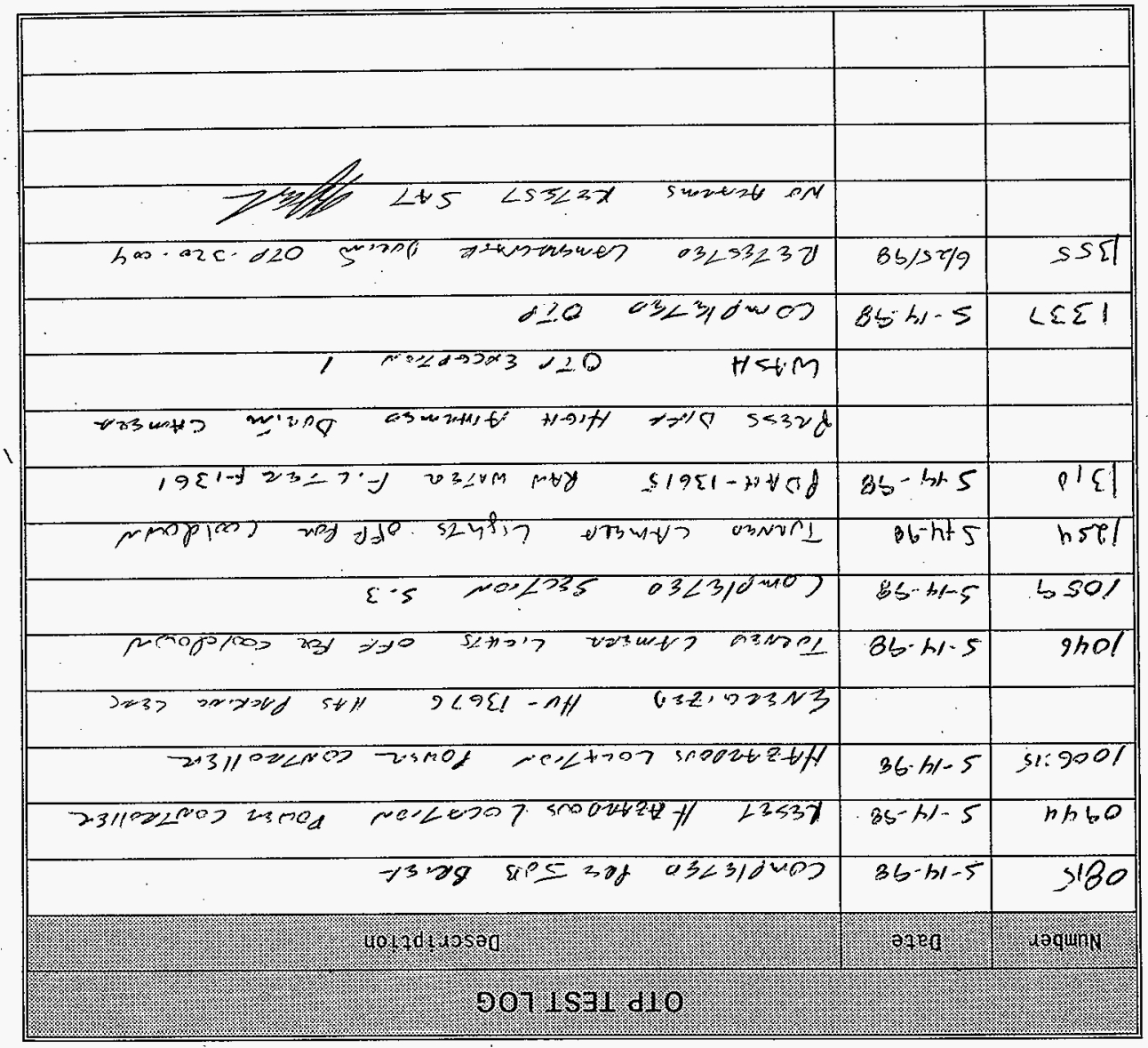




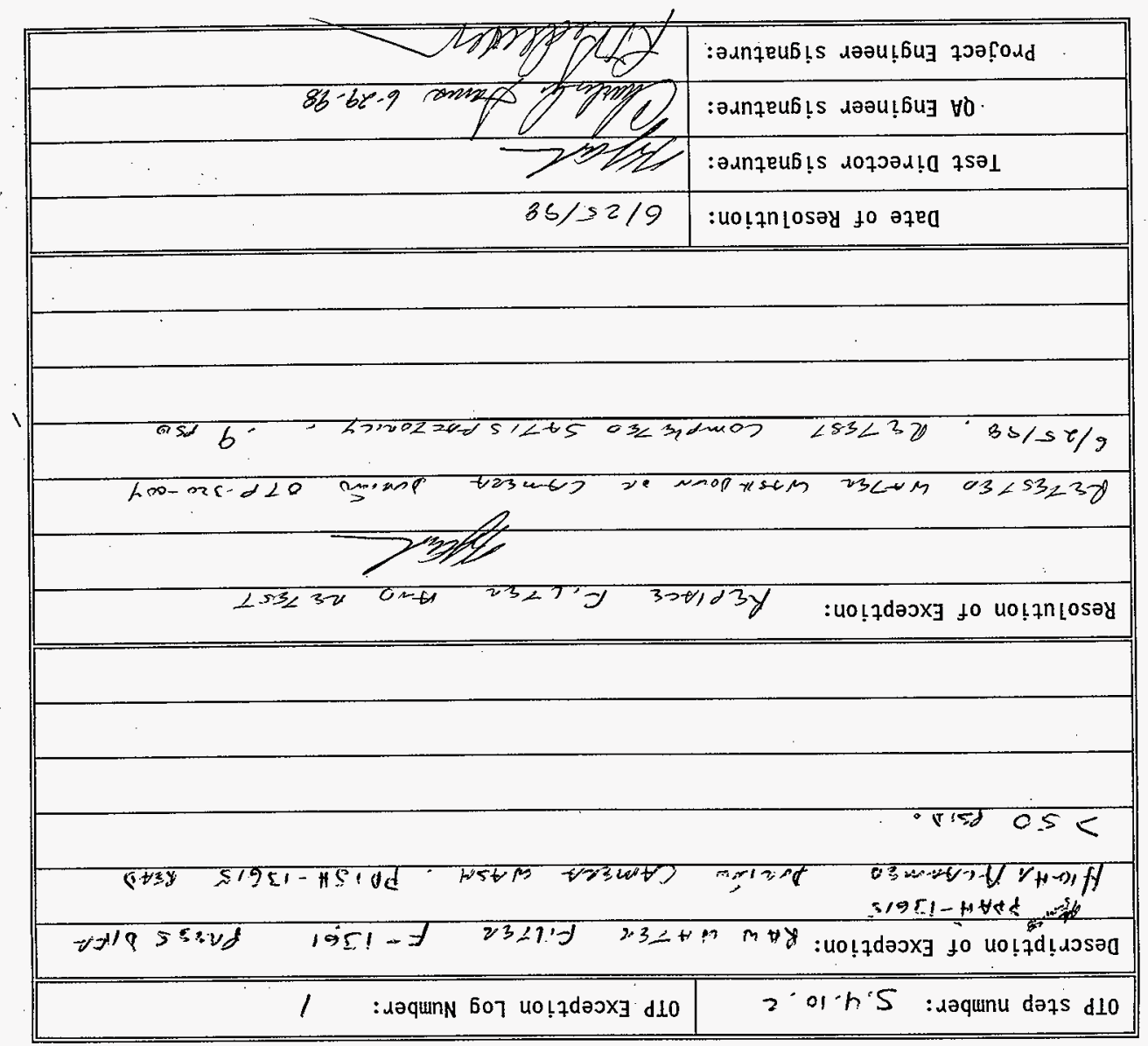

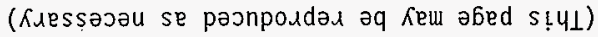

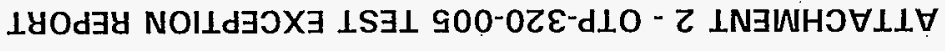


WORKING COPY

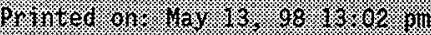

ATTACHMENT 3 - OTP-320-005 SIGNATURE LOG

All personnel participating in the performance of this operational test procedure shall enter their printed name, signature and initials below.

NAME (PRINT)

Dow Elliot

Mic. Winfield

Bran Belem

Jack Bottemillea

Al Almoust

DR Jones

CW Peak

Grepon J.Sullivian

Woodcock

LTPedersen

KJ Avoresor

wt. CAmlet)

Charles A: Sans
SIGNATURE
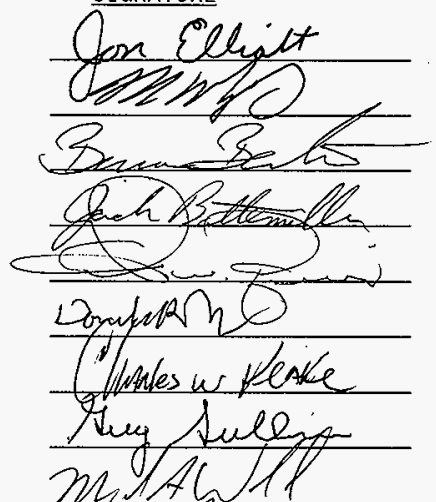

mathelewer

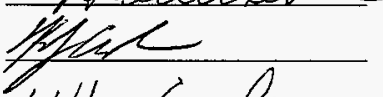

INITIALS

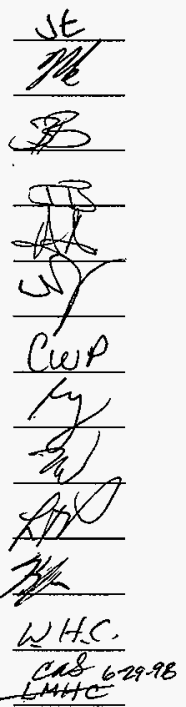

HNF-2950, Rev. 0

A-28

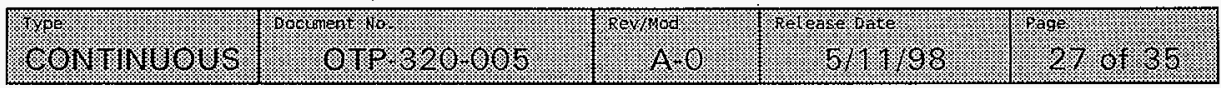


ATTACHMENT 4 - OTP-320-005 ELECTRICAL LINEUP

\begin{tabular}{|c|c|c|c|c|}
\hline DISCONNECT/BREAKER & 14 LOCATION & POSHIION & & DATE \\
\hline $\begin{array}{l}\text { MCC NI, } \\
\text { IFDR PROGESS BUILOING }\end{array}$ & $\begin{array}{l}\text { Electrical Equipment } \\
\text { Skid } 241-c-51\end{array}$ & ON & & $5 / 14 / 98$ \\
\hline $\begin{array}{l}\text { PNL MO211, BKR \#3, } \\
\text { CP-O2 IN TANK IMAGING } \\
\text { RCPTS }\end{array}$ & $\begin{array}{l}\text { Control Room } \\
\text { Mo } 211\end{array}$ & . $0 \mathrm{~N}$ & & 13 \\
\hline $\begin{array}{l}\text { DS 1, PROCESS } \\
\text { BUILDING MAIN } \\
\text { DISCONNECT SWITCH }\end{array}$ & Rack ER-1 & ON & & $5 / 14 / 98$ \\
\hline $\begin{array}{l}\text { SUPPLY-CB-01, PROCESS } \\
\text { BLDG POWER PANEL PP-1 }\end{array}$ & Rack ER 1 & $O N$ & & $5 / 14 / 98$ \\
\hline MAIN & $\begin{array}{l}\text { Process Buyding } \\
241-C-91 \text {, Room } 2\end{array}$ & ON & & $5 / 14 / 98$ \\
\hline $\begin{array}{l}\text { C106-PP1, } \\
\text { SECONDARY MAIN }\end{array}$ & Process Buil lalng & ON & & $5 / 14 / 98$ \\
\hline $\begin{array}{l}\text { CIO6-PPI, BKR \#.5 } \\
\text { INSTRUMENTATION }\end{array}$ & $\begin{array}{l}\text { Process Building } \\
241-c-91 \text {, Room? }\end{array}$ & ON & & $5 / 14 / 98$ \\
\hline 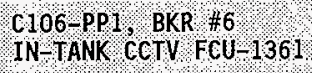 & $\begin{array}{l}\text { Process Bullding } \\
241-\mathrm{C}-91 \text {, Room } 2\end{array}$ & $0 \mathrm{~N}$ & & $5 / 14 / 98$ \\
\hline C106-PP1, BKR \#9 & $\begin{array}{l}\text { Process Builoing } \\
241-\mathrm{C}-91 \text {, Room } 2\end{array}$ & ON & $<$ & 5 \\
\hline
\end{tabular}

HNF-2950, Rev. 0 
0 '

\begin{tabular}{|c|c|c|c|c|}
\hline $\mathrm{sb} / \mathrm{hl} / \mathrm{s}$ & $\leqslant$ & $\mathrm{N} \exists \mathrm{dO}$ & flddns sRs butfeluI & $80 \mathrm{~T} 9 \mathrm{EL} \mathrm{NH}$ \\
\hline $86 / \mathrm{hl} / \mathrm{s}$ & 7 & 035070 & 7OLUI 29عI-J & $9998 \mathrm{I}-\mathrm{AH}$ \\
\hline$s b / h / s$ & & $0 \exists S 070$ & osI forulos asoH & $8998 \mathrm{~L} \wedge \mathrm{H}$ \\
\hline $8 b / h 1 / S$ & & $\mathrm{NBdO}$ & 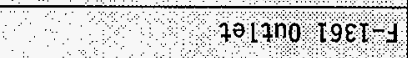 & $7998 \mathrm{I}-\Lambda \mathrm{H}$ \\
\hline $26 / \mid 71 / 5$ & & NadO & $7 \partial 17$ O GI9\&T HSTOd & $8698 \mathrm{I} A \mathrm{H}$ \\
\hline $86 / \mathrm{h} / \mathrm{s}$ & & $\mathrm{N} \exists \mathrm{dO}$ & $7 \partial$ LI ST $98 \mathrm{H}$ HSIOd & $669 \varepsilon \mathrm{I} / \mathrm{H}$ \\
\hline $86 / \mathrm{H} / \mathrm{s}$ & & $\mathrm{NGdO}$ & $7 \partial[41$ เ9\&1 & $899 \& \mathrm{I}-\Lambda \mathrm{H}$ \\
\hline $8 b / h i / s$ & & a3s073 & $4 \mathrm{l}$ lod leas & $80 T 98 \mathrm{I} \Lambda \mathrm{H}$ \\
\hline $8 b / \mathrm{h} / \mathrm{s}$ & & 035070 & oSI $70 a 4 u O J$ osOH & $20198 \mathrm{~T} / \mathrm{H}$ \\
\hline sb/h1/s & & $N \exists d O$ & $7 \% 1710298 \mathrm{I} \mathrm{dg}$ & I998I AH \\
\hline sb/h/s & & N3dO & ғә L U $29 \varepsilon \mathrm{I} \mathrm{dg}$ & $099 \varepsilon I_{1 H}$ \\
\hline $8 b / h 1 / 9$ & & assoto & Ulela lofen Mey & $0698 \mathrm{I}-\mathrm{AH}$ \\
\hline $8 / h / h / s$ & $f$ & N $\exists d O$ & OST $6 \mathrm{P} / 8$ I6-ง-Ttz & $6998 \mathrm{I}-\mathrm{AH}$ \\
\hline उ॥० & BUIINI & NoI ISOd & NOIIdIYJSJO & 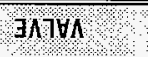 \\
\hline
\end{tabular}


ATTACHMENT 6 - OTP-320-005 COMPRESSED AIR VALVE LINEUP

\begin{tabular}{|c|c|c|c|c|}
\hline VAL VE & DESCRIPTION & POSITION & INIIAL & DATE \\
\hline $\mathrm{HV}-13687$ & 241 -c-91 B1dg Iso & OPEN & $\Delta$ & $5 / 14 / 98$ \\
\hline $\mathrm{HV}-13671$ & $\mathrm{HV}-13669 \mathrm{Iso}$ & CLOSED & L & $5 / 14 / 48$ \\
\hline$H V-13689$ & $\mathrm{HV}-13638 \mathrm{lso}$ & CLOSED & If & $5 / 14 / 6$ \\
\hline $\mathrm{HV}-13678$ & $\mathrm{TK}-1364 \mathrm{Inlet}$ & CLOSED & Dy & $5 / 14 / 98$ \\
\hline $\mathrm{HV}=136158$ & Tank Press Iso & CLOSED & DY & $5 / 14414$ \\
\hline $\mathrm{HV}-13613$ & Vortex Iso & CLOSED & D & $5 / 14 / 98$ \\
\hline $\mathrm{HV}-1369$ & Imaging Sys supply & OPEN & DO & $5 / 14 / 98$ \\
\hline $\mathrm{HV}-13610$ & $\mathrm{PI}-13628 \mathrm{lsO}$ & OPEN & Do & $5 / 14 / 98$ \\
\hline
\end{tabular}

HNF-2950, Rev. 0

$$
\text { A-31 }
$$




\section{ATTACHMENT 7 - OTP-320-005 ALARM RESPONSE}

FACILITY: 241-C-91 Process Building

PANEL: $\quad$ ANN-1362

ALARM \#: $\quad 3-4$

SOURCE: PDISH-13615

SETPOINT: $\geq 30$ in. $w g$

ALARM CLASS: $\quad$ Equipment Status

Alarm Description: Differential pressure across Filter F-1361 is 30 in. wg or higher. Automatic Action:

Activates M0-211 Control Room aTarm, Cabinet CP-01, TANK 241-C-106 HVAC SYSTEM TROUBLE (XA-1368).

Operator Actions:

[1] CHECK differential pressure indication on PDISH-13615.

[2] IF indication $\geq 30$ in. wg, CHECK Filter F-1361 for leakage, or noticeable signs of plugging or clogging.

[3] NOTIFY Shift Manager of findings.

Possible Causes: $\quad$ 1. Filter becoming plugged.

2. Instrument malfunction.

References:

$\mathrm{H}-2-818561-3$ \& $-5, \mathrm{H}-2-818603-6$

TO-320-010

HNF-2950, Rev. 0

A-32 


\section{ATTACHMENT 7 - OTP-320-005 ALARM RESPONSE (Cont.)}

FACILITY: MO-211 Control Room

CABINET : $\quad$ CP-01

PANEL: $\quad$ ANN-1361

ALARM \#: $3-3$

SOURCE: See Alarm Inputs Below

SETPOINT: $\quad N / A$

ALARM CLASS: Equipment Status

Alarm Description: Trouble with Process Building 241-C-91 HVAC System equipment.

Operator Actions: [1] NOTIFY Shift Manager.

[2] CHECK Process Building 241-C-91 Room 2, Instrument Enclosure IE-1361, Annunciator ANN-1362 alarms.

[3] NOTIFY Shift Manager of findings.

\begin{tabular}{lll}
\hline Possible Causes: & 1. & Equipment becoming plugged \\
& 2. & Equipment malfunction \\
& 3. & Instrument malfunction \\
& 4. & Power loss \\
& 5. & Maintenance work
\end{tabular}

References: $\quad \mathrm{H}-2-818561, \mathrm{H}-2-818601, \mathrm{H}-2-818603$

T0-320-010, T0-320-012

Alarm Inputs:

IAH-13635

LAH-1369

LAL -1368

LAL-1369

PDAH-13611

PDAH-13612

PDAH-13613

PDAH-13614

PDAH-13615
HVAC SYSTEM

TROUBLE

(XA-1368)
TANK 241-C-106

ALARM \#: $3-3 \quad$ (XA-1368)

WHITE 


\section{ATTACHMENT 7 - OTP-320-005 ALARM RESPONSE (Cont.)}

FACILITY: M0-211 Control Room

CABINET: $\quad \mathrm{CP}-01$

PANEL: $\quad$ ANN-1361

ALARM \#: $\quad 6-1$

SOURCE: LDS-1365

SETPOINT: $\quad N / A$
WHITE

\section{C-FARM SVCE BLDG \\ LEAK DETECTED (LDA-1365A)}

\section{ALARM CLASS: $\quad$ Plant Stability}

Alarm Description: $\quad$ Service Building 241-C-73 Backflow Preventer BP-1361 is leaking.

Automatic Action: Tank Monitor And Control System (TMACS) alarm is also activated.

Operator Actions: [1] NOTIFY Shift Manager AND CASS/TMACS Operator.

[2] DETERMINE if raw water is leaking in Building 241-C-73.

[3] PERFORM actions required in ARP-T-331-00004, Respond to Alarms at Service Building 241-C-73.

\begin{tabular}{lll}
\hline Possible Causes: & 1. & Faulty, leaking backflow preventer \\
& 3. & Broken pipe, leaking fitting \\
& 2. & Faulty sensor, instrument malfunction
\end{tabular}

References:

$\mathrm{H}-2-818562, \mathrm{H}-2-818601, \mathrm{H}-2-818675, \mathrm{H}-2-818677$

T0-320-010

HNF-2950, Rev. 0

A-34 


\section{ATTACHMENT 7 - OTP-320-005 ALARM RESPONSE (Cont.)}

FACILITY: M0-211 Control Room

CABINET : $\quad$ CP-01

PANEL: $\quad$ ANN-1361

ALARM \#: $6-2$

SOURCE: See Alarm Inputs below

SETPOINT: N/A
WHITE

\section{C-FARM SVCE BLDG AIR \& WATER SYS TROUBLE (XA-1367)}

\section{ALARM CLASS: Plant Stability}

Alarm Description: Equipment trouble in Service Building 241-C-73.

Operator Actions: [1] NOTIFY Shift Manager.

[2] CHECK Service Building 241-C-73, Annunciator ANN-1364 alarm indications.

[3] RESPOND to alarms at Air and Water Service Building 241-C-73 per ARP-T-331-00004.

\begin{tabular}{lll}
\hline Possible Causes: & 1. & Compressor CPR-1361 trouble \\
& 2. & Air dryer D-1361 trouble \\
& 3. & Plugged filter \\
& 4. & Raw water strainer F-1363 becoming plugged \\
& 5. & Building temperature high or low \\
& 6. & Instrument malfunction
\end{tabular}

References: $\quad \mathrm{H}-2-818562, \mathrm{H}-2-818601, \mathrm{H}-2-818675$

T0-320-010, T0-320-012

Alarm Inputs:

PAL-1364, PDAH-1365, TAH-13617, TAL-13617, XA-1363

HNF-2950, Rev. 0

A- -35 


\section{PROCEDURE HISTORY SIGNATURE SHEET}

HNF-2950, Rev. 0

A-36 


\section{RAW WATER USAGE DATA SHEET* \\ DATA SHEET 3}

NOTE - One data sheet is to be used for each water usage activity.

Date $5 \cdot 14-58$

Time $/ 423$

Tank farm area in. which water is to be used: $\quad c-f_{-a, n}$

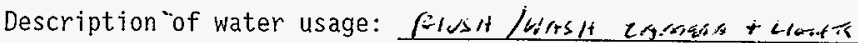

Approximate amount of water needed: 75 Garrom Leakage amount:

$\not$

Where will this water drain: $2 y / .<-106$

If water drains to a single shell tank, approvals are required and documented below.

( ) Routine water usage for contamination control and construction support.

( ) Routine water addition to Tank C-106 using procedure T0-350-200 or Waste RetrievaT Sluicing System HVAC procedure ATP-320-0012.

( ) Process memo issued by Tank Farm Systems Engineering authorizing water additions to support jet pump startup, or water addition authorized by procedure. $\underline{500}$ GALLON LIMIT

$2\{.97 .223$ O Otf 320.005

Procedure Number or Process Memo Number

(2) If usage does not meet the above criteria, the following approvals are required prior to water usage.
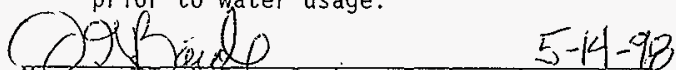

Manager, Fank Takm Systems Engineering - Date

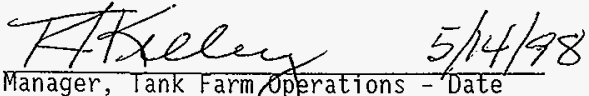

Functional Test

Water meter functioning properly?

Yes[V] No[ ]

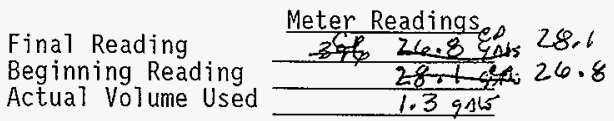

Water Meter Functional Verification Method Digiafe indrention

Operator's Initials

$\cos \varphi$

TFo Shift Manager Review

$5-14-98$

HNF-2950, Rev. 0

A- 37 